\section{Digital commoning and its challenges}

\section{Wessel Reijers}

Dublin City University, Ireland

\section{Marinus Ossewaarde}

University of Twente, The Netherlands

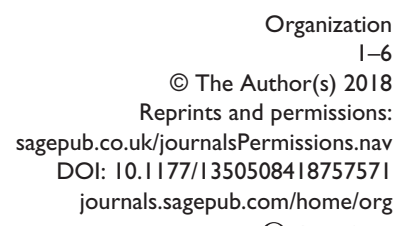

@SAGE

\begin{abstract}
This article is a reply to Kostakis' paper 'In Defense of Digital Commoning'. It welcomes the criticisms raised by Kostakis against our initial account of the Illusion of the Digital Commons. We argue that we can largely defend our initial account by (I) justifying our choice for discussing 'hybrid' forms of digital commoning, (2) explaining the strategy of our approach, and (3) offering an additional critique of the digital platform as a basis for political action.
\end{abstract}

\title{
Keywords
}

Digital commoning, false consciousness, illusion of the digital commons, platform economy

\section{Introduction}

In a paper titled The Illusion of the Digital Commons, we introduce an alternative perspective on the digital commons discourse (Ossewaarde and Reijers, 2017). In this article, a number of central claims are made: (1) that through technologically mediated practices of digital commoning, implicit and explicit pricing mechanisms can be realized, (2) that such mechanisms draw the practices of digital commoning towards the monetary economy, and (3) which in turn affects the forms of resistance that are implied in practices of digital commoning. Ultimately, we argue that digital commoning tends to foster a 'false consciousness' that Sloterdijk (1987) has unmasked as 'cynicism'. In the context of the digital commons, we characterized such cynicism as marked by digital commoners who are disillusioned by 'the power of things', or the power of technology. As a result, we argue that the emancipatory potentials of digital communing are rather limited. Overcoming the 
illusion of the digital commons would require a 'free' relationship to technologies - but this type of freedom is difficult to achieve in a capitalist technological society in which technology embodies capitalist values and interests.

Kostakis (2018) raises a number of important criticisms concerning our account of the illusion of the digital commons. First, he criticizes our choice of discussing hospitality exchanges as digital commoning practices. He stresses that such exchanges do not fit our initial characterisations of the digital commons according to the property of rivalness (meaning that a person who opts for using a certain resource subtracts from the ability of someone else to do the same) and the criterion of caretaking by a community. Second, he criticizes our characterisation of digital commoning practices as 'a-political'. Kostakis argues that we fail to comprehend the fundamental difference between commons-based peer-to-peer production (CBPP) and the capitalist economy, and that we fail to recognize the alleged existence of a community ethos on digital commons platforms. We welcome Kostakis' critical remarks, and we believe that our initial paper may have given rise to some misunderstanding, particularly when it comes to our use of the problematic term 'a-political'. Kostakis' criticism helpfully points at the need for further clarification with regard to some of the strategies we have employed in our paper. However, we do think that through providing a number of such clarifications in this reply, the central thesis of The Illusion of the Digital Commons can be defended.

To start, we would like to emphasize that our paper does not intend to 'attack' practices of digital commoning. It does not aim at disqualifying the myriad of promising, emancipatory projects that are identified in one way or another with the idea of the digital commons. On the contrary, we are sympathetic to concrete projects that are experimenting with digital commoning and alternative economies. Yet, we have strong doubts about digital commoning as an emancipatory force that could generate a post-capitalist world. Our article offers a lens through which to engage in what could be a fruitful critique that does not take some basic assumptions of a somewhat over-enthusiastic digital commons discourse for granted. It does not necessarily follow that we believe that all digital commoning practices are non-emancipatory, but that a number of them might, which in turn represents a potential problem that our paper aims to uncover. Eventually, the purpose of our paper is not to attack digital commoners or the digital commons discourse, but rather to critically reflect on the emancipatory potentials of digital commoning in the negation of 'false consciousness'.

Furthermore, some of the issues brought up by Kostakis are dealt with in our paper, at least up to a certain point. For instance, we discuss why Airbnb should not be considered a hospitality exchange (and, accordingly, should not be considered as a digital commons). And we do explain in our paper why we nevertheless decided to include Airbnb in our analysis: because it illustrates the move towards marketization that is implied in the notion of the illusion of the digital commons (Ossewaarde \& Reijers, 2017: 615). We believe it is unfortunate that a large section of the argument in our initial paper was left out of Kostakis' reply, as we feel that we do respond in our paper to the concerns that Kostakis raises. In the remainder of our reply to Kostakis, we respond to his criticism in three ways. First, we provide a justification for our choice of 'hybrid' forms of digital commoning, which are forms of hospitality exchange. Second, we explain the strategy that we apply in our unmasking of the illusion of the digital commons. Third, we offer an extended critique of the alleged emancipatory potential of digital platforms to function as political tools that might subvert the logic of capitalist modes of production.

\section{The concept of 'hybrid' digital commoning}

We think that a first misunderstanding arises from our use of 'hybrid' forms of digital commoning, as contrasted with the allegedly 'pure' informational forms of digital commoning (e.g. Wikipedia) that we believe are implied in Kostakis' reply and characterized by their forms as 'knowledge', 
'software' and 'design' (Kostakis, 2018: 3). We opted to use hybrid forms of digital commoning as our central example because such forms most strongly reveal the frictions that arise when digital structures interact with material reality, through human practices. Uber taxi drivers take the streets, homeowners who use Airbnb start to protest against their local governments, but Wikipedia users rarely engage in any activity that could be labelled political in a similar sense. Kostakis mentions some 'pure' (entirely digital) informational digital commons such as Wikipedia and Linux as prime examples of digital commoning platforms that negate or challenge the capitalist economy. We, however, have serious doubts about the emancipatory potentials of these types of platforms. On the surface, one could indeed argue that for instance Wikipedia has displaced out-dated corporate models, such as the Encyclopaedia Britannica. Wikipedia, however, has also fuelled corporate activities of Internet giants and powerful localisation services. Companies such as Google even actively donate funds to Wikipedia (Johnson, 2010). Wikipedia, therefore, does not seem to pose a threat to capitalist business logic. Notwithstanding the great merits of collective knowledge production and sharing, it does not seem to be at odds with capitalist modes of production. In other words, its emancipatory power for shaping a post-capitalist world appears rather limited.

Global injustice that is caused by capitalist modes of production largely emerges as forms of inequality in which the digital and the material intersect. People have to face shortages of material goods, are limited in their ability to move physically across borders, and have unequal access to services such as healthcare and education that still largely rely on material infrastructures. Even 'pure' informational digital commons like Wikipedia rely on material infrastructures of glass fibre cables, server parks, and so on. Our consistent use of quotation marks thereby indicates that we do not believe that 'pure' informational digital commons actually exist. We do believe that the degrees to which practices of digital commoning mediate material reality can differ. Forms of digital commoning that are hybrid to a greater extent such as hospitality exchange and care sharing are more interesting in the context of our argument because they do, due to their extended embeddedness in our material reality, at least appeal to the promise of going against capitalist modes of production - something that a platform such as Wikipedia does not seems to do.

Subsequently, we think that hospitality exchange is particularly relevant as an example of a practice that, to a certain extent, manifests the ethos of digital commoning understood as sharing. It is particularly illustrative of what Ricoeur designates as an 'ethics of reciprocity, of sharing, of living together' (Ricoeur, 1992: 187-emphasis added). The hospitality exchange confronts us with the underlying idea of sharing that is clearer than the practice of sharing of information or digital objects. When a house is shared between its owner and a guest, the guest, to some extent, becomes the owner; and the owner, to some extent, becomes the guest. The act of hospitality therefore opens up the enclosed realm of a household to the 'other' and turns it into a commons. This is a practice that can disrupt capitalist modes of production, because it revolves around a type of reciprocity that is different from the reciprocity inherent to the monetary economy, which we capture by Simmel's notion of exchange in which no exchange of sacrifices takes place. Therefore, our focus on the ways in which digital architectures mediate the act of hospitality, understood as a commoning practice, is highly relevant for the purposes of our article.

\section{Our strategy for unmasking the illusion of the digital commons}

Different strategies of enquiry can be imagined in approaching the topic of the digital commons from a critical angle. First, we can consider the focus of the analysis. Of what do we think, talk and write about when we discuss the digital commons? Do we consider digital commons as resources or as practices? Second, we can consider the focus of the comparison of digital commons with other economic forms. Do we focus on their differences or their commonalities? 
As Kostakis admits, the understanding of the digital commons through the notion of practice is a promising one. However, he also quickly reverts back to an understanding of digital commons as a resource. He declares that a digital commons should be understood as a 'shared informational resource'. In our paper, we initially discuss digital commons both as a resource through the lens of Ostrom's (1990) theory and as a certain type of activity through the lens of Benkler's and Nissenbaum's account (Benkler and Nissenbaum, 2006). However, we explicitly emphasize that we use these two contrasting categorisations as initial characterisations of the commons (Ossewaarde and Reijers, 2017: 612). Eventually, we deliberately endorse neither of the two contrasting views. Instead, we provide an alternative account of digital commoning for which we use Georg Simmel's (1978 [1900)) theory of money. We use the two initial accounts of the commons to argue that if we consider digital commons as resources in Ostrom's sense, at least Couchsurfing and BeWelcome can be defended as such. In this context, we explicitly state that the 'free riding' problem does not apply to platforms using explicit pricing, such as Airbnb. Similarly, if we consider digital commons as discrete individual efforts that contribute to the activity of pooling, the characterization of the platforms we discuss as digital commons can also be defended. However, we believe that both initial accounts of the digital commons fail to unmask digital commoning a non-emancipatory force. In our unmasking of the illusion of the digital commons, we make the idea of the digital commons as a practice more explicit. We base the idea of digital commoning practice on 'crucial technologically mediated activities' (Ossewaarde and Reijers, 2017: 616) that are rendered intelligible through the use of Simmel's theory of money. From such a characterization of the digital commons it follows that shared living spaces and Wikipedia entries might indeed be very different things, but the technologically mediated practices by which they are pooled tie them together.

Our article seems to have generated another misunderstanding. We deliberately set out to discuss commonalities of practices of digital commoning; yet, Kostakis has the impression that our article focuses on differences. Kostakis emphasizes that 'digital commons' that belong to the rental economy and digital commons 'proper' should not be confused. And he stresses that companies operating in rental economy should not misuse the word 'sharing'. At first sight, these claims seem to be in agreement with ours. However, we observe that even though digital commons and the rental economy should not be confused and that the word sharing should not be misused, they nonetheless typically are. Our follow-up question that we pose in our article is therefore: why is this the case? In his reply to our paper, Kostakis seems to focus on differences between false 'digital commons' and digital commons proper. He argues that 'if there is no sharing, there is no commoning' (Kostakis, 2018: 3). In the light of our article, this begs the question: what is 'sharing' and what would qualify the respective practices as such?

In our article, the strategy for finding an answer to this question is first of all to look for commonalities between the different pooling practices in question, and second, to look at differences. We initially observe that the technologically mediated practices of pooling on different types of hospitality exchanges are very similar. We show that such practices all revolve around the creation of individual accounts, the creation of digital representations of living spaces and digital profiles with reputation mechanisms attached to them (Ossewaarde and Reijers, 2017: 616). Such features make them different from traditional commoning practices, where no creation and maintenance of accounts, representations of resources and reputation mechanisms are needed. It is this tension of commonalities between digitally mediated practices of commoning and differences between these practices and form of traditional commoning that is the focus of our article.

\section{Are digital platforms political vehicles?}

Finally, Kostakis argues that our article unjustifiably characterizes digital commoning as 'a-political' (Kostakis, 2018: 3). We admit that our choice of wording is unfortunate, as the term in question may well lead to the impression that we assume technological mediation as such to be a-political. 
However, in the context of unmasking the illusion of the digital commons, we believe that another interpretation is warranted: we use the term a-political to emphasize that the emancipatory power in the negation of 'false consciousness' is limited. For Kostakis, commons-based peer production (CBPP) is a political practice that does subvert capitalist modes of production. Yet, as we have discussed above, digital commoning platforms like Wikipedia live happily alongside the capitalist economy; and even fuel it. The same goes for a number of open-source projects that Kostakis mentions, including Linux and Mozilla Firefox. We do believe it is true that CBPP is significantly different from value creation in industrial capitalism, yet, it is rather similar to the dominant economic model of 21 st century post-industrial capitalism, which Srnicek labels 'platform capitalism' (Srnicek, 2016). One of the points of our article is to pinpoint the affinity between 'digital commoning' platforms and digital platforms that perpetuate capitalist modes of production, both of which contradict the 20th-century paradigm of industrial capitalism.

Kostakis refers to Feenberg's work to explain that the use of concepts such as 'peer-to-peer' should not be understood as a-political. In line with Feenberg, we admit that technology is not neutral. Yet, Feenberg also argues that public interventions in technology often appear a-political due to their success. He stresses that 'lay initiatives usually influence technical rationality without destroying it'. And he points out that technical professions 'usually succeed in translating political demands into technically rational terms' (Feenberg, 1999: 89-90). In other words, even though a concept such as 'peer-topeer' - which originally designates distributed application architectures - might have led to public interventions in technology design, it is still questionable whether the underlying technical rationality has been affected. As such, in the words of Hannah Arendt, we might say that even though the concepts of digital commoning are not a-political as such, they nevertheless remain confined to the world of work, of homo faber; and they do not (yet) translate into the world of political action of zoon politikon (Arendt, 1958). In this sense, assessing the alleged potential of digital commoning platforms in terms of their production of 'sophisticated products' that are 'better' than those produced through marketbased mechanisms, as Kostakis concedes, does not say much about their emancipatory power.

Kostakis admits that digital commoning platforms might become an 'essential ingredient of capitalism' (Kostakis, 2018: 5). His observation is in line with our argument, but in contrast to ours Kostakis presents it as a merit. Kostakis offers a somewhat Hegelian picture of the digital commons being an anti-thesis to the domination of capital and state, ultimately resulting into a synthesis of opposites in a new, commons-centric capitalism. It is not clear what such a commons-centric capitalism would look like and how it would subvert current inequalities and injustices that are perpetuated through capitalist modes of production. Considering the increasing dominance of digital platforms, and 'platform capitalism' in general, the future would not seem very bright for those seeking to negate false consciousness through practices of digital commoning. We therefore conclude that even though digital commoning practices are indeed not strictly 'a-political', such practices nevertheless do not necessarily live up to the notion of political action that would be capable of radically subverting the capitalist modes of production.

\section{Conclusion}

Kostakis (2018) has raised a number of issues for debate that result from our article on the illusion of the digital commons. We welcome his criticisms and find them most helpful for refining our initial argument and for clarifying parts of the strategy that we actually taken in our article. Kostakis' first point of criticism is that our article, by choosing hospitality exchanges as illustrative examples, confuses the renting economy with digital communing. We reply that such 'hybrid' forms of digital commoning are chosen because (1) they show most clearly how digital architectures bring about social friction in the material world and (2) because we focus on the digital commoning as a practice that is mediated by digital technologies. Kostakis' second point of criticism is that we position current digital commoning practices as 'a-political', while technology is not 
neutral and inherently political. We reply that digital commoning is indeed not neutral, but that it perpetuates a technical rationality that prevents it from being translated into an emancipatory practice that contains a political potential for negating 'false consciousness'.

To finish, we would like to offer two suggestions based on our extended critique. First, we suggest that digital commoners be critical about the types of relations they facilitate through digital platforms and whether these relations might unintentionally have a close affinity with capitalist modes of production. For instance, reputation mechanisms and identity mechanisms that are crucial for the functioning of digital platforms might be at odds with the ethos of commoning, understood as an ethos of sharing in which oneself confronts the (unknown) other, and might engender practices that move close to the reciprocity that is central to the monetary economy. Accordingly, capitalist measures of success, such as 'efficiency', should be used with extreme caution in assessing the benefits of digital commoning practices. Second, we suggest that digital commoning might be successful in negating capitalist modes of productions, but only when embedded in a framework of political action that itself surpasses the notion of digital commoning. Too often, we argue, instruments for political action become the focal point of political action themselves.

\section{Funding}

The ADAPT Centre for Digital Content Technology is funded under the SFI Research Centres Programme (grant 13/RC/2106) and is co-funded under the European Regional Development Fund.

\section{ORCID iD}

Wessel Reijers (iD https://orcid.org/0000-0003-2505-1587

\section{References}

Arendt, H. (1958) The Human Condition. Chicago, IL: University of Chicago Press.

Benkler, Y. and Nissenbaum, H. (2006) 'Commons-Based Peer Production and Virtue', Journal of Political Philosophy 14(4): 394-419.

Feenberg, A. (1999) Questioning Technology. New York: Routledge.

Johnson, B. (2010) 'Wikipedia Wins the Google Lottery but Why?'. Retrieved December 4, 2017, from https://www.theguardian.com/technology/blog/2010/feb/18/wikipedia-google

Kostakis, V. (2018) 'In Defense of Digital Commoning', Organization. DOI: 10.1177/1350508418757571

Ossewaarde, M. and Reijers, W. (2017) 'The Illusion of the Digital Commons: 'False Consciousness' in Online Alternative Economies', Organization 24(5): 609-628.

Ostrom, E. (1990) Governing the Commons: The Evolution of Institutions for Collective Action. Cambridge: Cambridge University Press.

Ricoeur, P. (1992) Oneself as Another (K. Blamey, ed.). Chicago, IL: University of Chicago Press.

Sloterdijk, P. (1987) Critique of Cynical Reason. Minneapolis: University of Minnesota Press.

Simmel, G. (1978 [1900]) The Philosophy of Money (D. Frisby, ed.), 3rd ed. New York: Routledge Classics. Srnicek, N. (2016) Platform Capitalism. Cambridge: Polity Press.

\section{Author biographies}

Wessel Reijers is a PhD researcher at the ADAPT Centre, Dublin City University. His research focuses on methods for practising ethics in research and innovation, virtue ethics of technology, hermeneutic approaches in philosophy of technology and the application of philosophical method to technologies such as cryptocurrencies and the digital commons.

Ringo Ossewaarde is an associate professor in Sociology of Governance in the Faculty of Behavioural, Management \& Social Sciences at the University of Twente. His research is concerned with the relationship between transformations, societal challenges, societal resilience, technology and governance issues in different policy areas and authority levels in globalizing European societies. 